Article

\title{
Disney's Reel Doubling of Violent Desire in J. J. Abrams' Mimetic The Force Awakens
}

\author{
John C. McDowell \\ Office of the Vice-Chancellor, University of Divinity, VIC 3052 Melbourne, Australia; \\ johnmcdowell1977@gmail.com
}

Received: 17 October 2019; Accepted: 4 November 2019; Published: 6 November 2019

\begin{abstract}
Abrams' spectacularly distended infantilising manipulation of the saga embeds a form of cognitive resonance with a state of perpetual war and a politically thanatising mythos fitted out as a politically containing moment within what cultural commentators are referring to as "post-9/11 American cinema", a form of cinema reacting to a cultural trauma and that normalises a hegemonic political reactivity in a perceived 'clash of civilizations' in "the social embodied" in an age marked by what Terry Eagleton describes as "holy terror". As cultural philosopher Douglas Kellner argues, movies of apocalyptic or catastrophe cinema can "be read as allegories of the disintegration of social life and civil society, and the emergence of a Darwinian nightmare where the struggle for survival occurs in a Hobbesian world where life is nasty, brutish, and short." The contention is that if George Lucas developed Star Wars to struggle with, among other things, an America that had elected Richard Nixon and engaged in the culturally traumatic Vietnam War, Abrams and his co-writer Lawrence Kazdan have relocated the franchise in a context marked as "post 9/11 cinema". It is unclear quite how The Force Awakens could offer a distinctively interrogatory function for conceiving political subjectivity in the contemporary fractured and self-assertive space of global geopolitics, expressing, as it does, the classificatory coding that figures innocent selfhood in a conflictual relation with the evil terrorist other. Abrams' movie, accordingly, is ill equipped to refuse to naturalise the innocence of the politically regulative messianic monomyth of the exceptionalist nation that instils a sensitivity conducive to violence against the foreigner when it is perceived to be under threat. It is, in other words, ill-equipped to resist being captured by the Girardian framing of myth within an identification of "sacred violence". Consequently, The Force Awakens provides a resource for the critic's reflections on the cultural difficulties of learning about our learning, of the disciplining of desire through monomythic intensification, and of sustaining reaction to cultural trauma through the hostility of sacrificial disposal of the other that requires the instrumentalised rationality of the self-secure national subject.
\end{abstract}

Keywords: mimesis; mimetic rivalry; sacred violence; scapegoat; cinema; culture; critical theory; post-9/11 cinema; disposability; instrumental rationality; realpolitik; otherness; alien; stranger; thanatology; star wars; J. J. Abrams; Disney; George Lucas

\section{Introduction: Formative Spectac-Ulations}

Something comparable with Hannah Arendt's concern about thoughtlessness notably emerges in Theodor Adorno's critique of the "entertainment industry". ${ }^{1}$ For him, the very business itself was an expression of the consumer culture's sigh of the oppressed masses, a shift in the provision of modes

1 See (Arendt 1969, p. 76; Adorno 1991). 
of mass (or better, cultural) consolation. As will be seen a little later, the appeal to the productions and function of popular culture in terms of Karl Marx's famous critique of religion is revealing of the way that the formations of the cultural imagination occurs in late modernity. "Culture", Terry Eagleton argues, "becomes a refuge from civil society rather than a means of transforming it." ${ }^{2}$ After all, cinema, especially popular blockbuster cinema, involves a linguistic simplism in its showings. It is not a discourse of debate, opposing viewpoints, or the like, but is comprised by what Pierre Bourdieu, speaking of journalism, calls "demagogic simplification". ${ }^{3}$ Moreover, it is caught within the controlling ambit of "corporate capitalism" and its reordering of value that captures, neutralises and domesticates "Every critical gesture". ${ }^{4}$ Where Adorno claimed that popular film was unable to challenge the system of oppression, other philosophers have been prompted to query, for example, whether films can do philosophy or engage in what theological ethicist Daniel Bell, Jr. calls "a therapy of desire" beyond being occasionally useful for illustrating thought. ${ }^{5}$ In fact, the market competition's regulation of the screened production reduces the shape and content of the products to entertainment, and to its "mechanical reproduction" so as to be "uncritically enjoyed". ${ }^{6}$ Such a cultural production leads to a culturally self-referential and "narcissistic complacency", of the spectacle of value-normalisation.

George Lucas' comments suggest that he was broadly aware of an Adorno-esque concern, one that was likely to have been mediated through Herbert Marcuse-film as a cultural artefact not only embeds cultural value but contributes to the process of enculturation. ${ }^{8}$ So he speaks of the filmmaker's large moral "megaphone" in the context of commenting on his or her social responsibility. ${ }^{9}$ Similarly, in the year of the release of Return of the Jedi (1983) he announced that "for better or worse the influence of the church, which used to be all powerful, has been usurped by film. Film and television tell us the way we conduct our lives, what is right and wrong." 10 This suggests that cultural artefacts are considerably more important than being simply ways of offering political distraction. Instead, they possess a pedagogical role. Put in Henry Giroux's terms, film possesses a cultural pedagogical significance that occurs through a process of coding, decoding and recoding of ideological value currents that produces cultural meaning. ${ }^{11}$ Such claims, of course, necessitates the need for a sustained critical reading in order to politically educate for cultural literacy, or to reflect on the nature of representation and the artifactual spectacle exhibiting dominant values of socio-political performance. While a number of commentators have immediately latched onto a thread that links, even if a little tenuously, Lucas to Joseph Campbell's monomythic structuration of the social imaginary, another set of commentators has nonetheless been particularly anxious that cinematic appeals to myth should not distract the gaze from cultural contextuality and the politics of cultural production and reception. ${ }^{12}$ (Of course, as soon as matters of 'myth' are mentioned, religion scholars tend to take note)

This paper focuses attention on a matter that has exercised several commentators' critical consideration-representations of violence, and violent representation in the Star Wars saga. It has become common for cultural analysts of screened culture to ask concerning the representations of violence and violent representationality, violent forms at the level of symbolic production, without

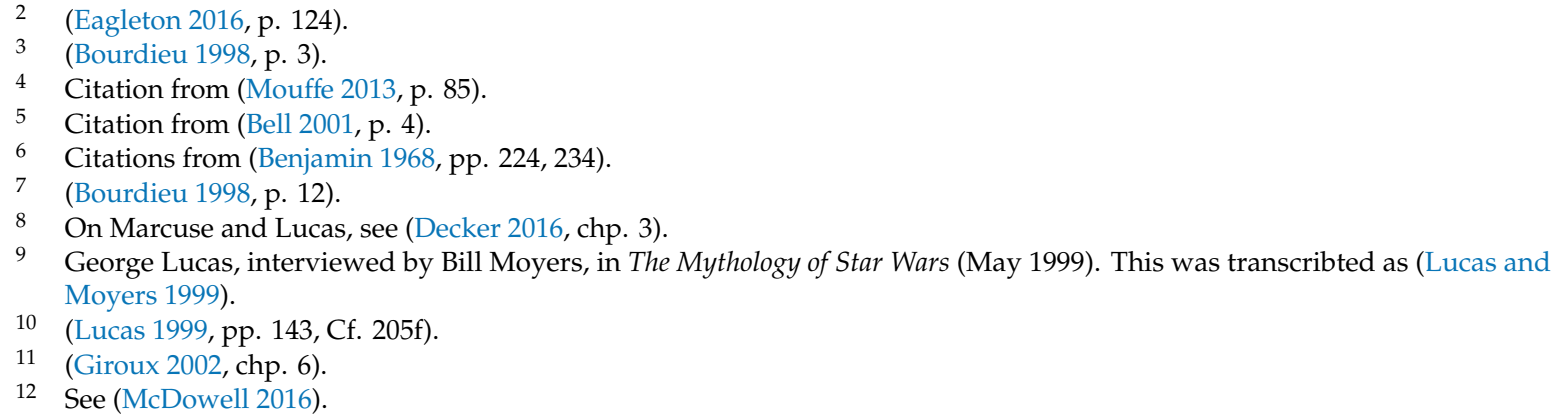


being bound to the hermeneutical naïveté of reducing meaning to authorial intention. ${ }^{13}$ Violence does not come from nowhere, but expresses deep cultural value-judgments from the disciplinary cultural habitus or acquired "structuring structures", whether that be what biblical scholar Walter Wink theologically describes as "the myth of redemptive violence", or the post-Hobbesian naturalised conditions of politically managing primitive violence that underlies the realpolitik. ${ }^{14}$ This is where the pressure of René Girard's analysis of the structuration of patterns of mimetic rivalry, or non-identically repetitive performance of violence, challenges reflection to move from moments of the appearance of the spectacle to the generative systems of projection of the spectacle. Girard identifies mimesis as the constitutive factor of the "Self", "the absolute condition for the existence of humanity". ${ }^{15}$ The pressure of his work to expose the arbitrariness of "sacred violence" subtly contests the socially dislocated subjectivity that has dominated self-identification in the cultural imaginary by socially embedding it. And it does so in a way that deconstructs the codings and their relationships to the politics of violence. In so doing, resistance is offered to naïve forms of the Romanticisation of cinema in terms of taste, choice and desire, themselves products of the enculturation of a culturally diffused Pietistic sensibility. Even when cinema attempts to depoliticise it, cinema production and its artefacts encode and present a series of assumptions about what is good and valuable without this appearing to view as anything other than natural. As Bourdieu argues, even the screen "which claims to record reality, creates it instead. We are getting closer and closer to the point where the social world is primarily described-and in a sense prescribed by" - that screen. ${ }^{16}$ This, of course, is precisely a matter of concern to religion scholars. Margaret Miles, for instance, explains why she, as a religious studies scholar, has studied matters of cinematic representation and expression of cultural value. "I work on popular film because it provides an index of the anxieties and longings of a large audience. I do so out of the conviction that religious scholars ignore this contemporary cultural 'text' at the cost of failing to engage the pressing concerns of this historical moment."17

Elsewhere critical work has contested the ease of textually loose, and conceptually unsophisticated critical readings of Lucas' Star Wars that align it with a textual dramatisation of a political conservativism that exhibits a violent soteriology. ${ }^{18}$ Largely these critiques operate from a reading of 1977's Star Wars (later named Episode IV: Star Wars. A New Hope), and even that is largely decontextualised. After all, this is the work of the writer of THX 1138 who had been equally engaged in the configuration of Apocalypse Now (which Francis Ford Coppola eventually directed once the commitment to the "Galaxy far, far away" became too distracting). ${ }^{19}$ What they all too rarely do is read Lucas' succeeding cinematic material as each offering a deconstruction of this body-docilising reading-possibility. Kellner announces that "The Star Wars films [of George Lucas] are ... polysemic, inviting multiple readings." 20 However, having dealt with this at some length elsewhere with regard to Lucas' pair of trilogies, the focal text of this paper becomes instead J. J. Abrams' The Force Awakens (2015). As such, the paper

13 According to Stuart Hall, "an ideological discourse does not depend on the conscious intentions of those who formulate statements within it." (Hall 1981, pp. 37f).

14 Citations from (Bourdieu 1990, p. 53; Wink 1998, p. 42).

15 (Girard 2003, p. 28).

16 (Bourdieu 1998, p. 22).

17 (Miles 1996, p. x). Miles, therefore, laments that “The field of 'religion and film' has been burdened by several less-than-fruitful approaches. Many reviewers for religious media have assumed that unless a film's primary content was explicitly religious it did not fall within the purview of religion and film." (p. xii).

18 See (McDowell 2016, chp. 1-2). While now a little old, the study by Michael Ryan and Douglas Kellner remains one of the more sophisticated versions of the claim that STAR WARS expresses a "conservative revolution" in the United States from the mid 1970s onwards, displaying the "triumph of conservative individualist models of social action" (Ryan and Kellner 1988, p. 219). "George Lucas's Star Wars", they argue, "has clear roots in ... nostalgic populism ... , but the series also espouses values of individualism, elite leadership, and freedom from state control which are congruent with the principles of the new conservatives of the eighties." (p. 228).

19 It is worth noting Mark T. Decker's reading: “George Lucas ... wove a popularization of Herbert Marcuse's critique of repressive, contemporary industrial society in his first film, 1971's THX-1138." (Decker 2016, p. 11).

20 (Kellner 2010, p. 182). 
forms a small part of a larger project that encourages appropriate thoughtfulness on the Disneyfying "retroactive defamiliarization" of the saga through the lens of Abrams' political apocalypticisation and Rian Johnson's counter-factually deconstructive desubjectifying in a tragic refusal to foreclose the future. ${ }^{21}$ I will not spend any time on the latter now, and I will not justify the distinguishing of Star Wars under Lucas and under Disney's proliferation of productive hands. Suffice it to say, though, that the fit between the two is a textual matter, and this is important for assessing the political significance of the increasingly disparate political visions that emerge from two incongruent sets of moral values. Abrams' spectacularly distended infantilising manipulation of the saga embeds a form of cognitive resonance with a state of perpetual war and a politically thanatising mythos fitted out as a politically containing moment within what cultural commentators are referring to as "post-9/11 American cinema", a form of cinema reacting to a cultural trauma and that normalises a hegemonic political reactivity in a perceived 'clash of civilisations' in "the social embodied" in an age marked by what Terry Eagleton describes as "holy terror". ${ }^{22}$ As Kellner argues, movies of apocalyptic or catastrophe cinema can "be read as allegories of the disintegration of social life and civil society, and the emergence of a Darwinian nightmare where the struggle for survival occurs in a Hobbesian world where life is nasty, brutish, and short." 23

\section{Identifying the Subject from Other as Alienated Stranger}

Predominantly critical attention on the foundations of violence alight on biological conditioning, a monstrosity or exception built into the very genetic makeup of persons in anomalous conditions. This, however, Hannah Arendt roundly rejects as problematic on a number of counts. ${ }^{24}$ For instance, it operates as something of a theodical-like justification that is all too prevalent in a variety of appeals to biology or nature that remain under the natural capacity of only the few. According to Girard, while "Ever since the romantic movement we have tended to see in the mythological monster a true creation ex nihilo, a pure invention", 25 "Violence is frequently called irrational. It has its reasons, however, and can marshal some rather convincing ones when the need arises.... It is generally assumed that collective violence-in particular, the pitting of all against one-is an aberration in the history of a society; a perversion more or less pathological in nature, whose study can hardly be expected to yield anything of sociological significance." ${ }^{26}$ To return momentarily to Arendt, it can be claimed that these justifying accounts are distractions from the enculturation and therefore history of violence. Violence is learned behaviour from within "an explicit ideological system", emerging from desire disciplined to become instinctive. What Arendt refuses is the pressure towards thoughtlessness, the failure to penetrate thoughtfully to causal conditions. ${ }^{27}$ Moreover, it is worth adding with Girard that the loss of the history of violence obscures the conditions for understanding the nature of the sacrificial and scapegoated victim. As he declares, "The victim is hard to recognize as a victim because he is totally monstrous." 28

After herself drawing heavily on Arendt's analysis, philosopher of religion Grace Jantzen appeals to Bourdieu's concept of the habitus. This is done to describe the socially constructing or enculturatingly productive process of violence in a way that lies beyond naïve and violence-rationalising appeals, for instance, to innate and inevitable aggressive personality disorders when attempting to understand the

21 The phrase is Ian Thomson's (Thomson 2005, p. 103).

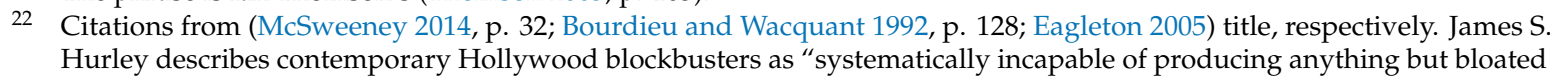
and infantilizing spectacle" (Hurley 2001, p. 93).

23 (Kellner 2010, p. 91).

24 See (Arendt 1969, pp. 59-64).

25 (Girard 1986, p. 33).

6 (Girard 1977, pp. 2, 81).

(Arendt 1969, p. 76).

8 (Girard 1977, p. 202). 
foundations of violence. This is more than simple habituating social mimesis, but rather involves an instinctivisation that is earthed in a mythos, or a mythic conditioning of social identification itself or the social imaginary as the conditions for understanding self and world, making judgments, planning for flourishing, and so on. ${ }^{29}$ Put another way, she argues, the habitus helps "determine what is morally thinkable. ${ }^{30}$ In this way, as philosopher of religion Richard Kearney declares, there is no simple and banal 'imitation', and certainly no arbitrary subjectivity and brutally radical indeterminism, but rather the "power of mimetic re-creation [that] sustains a connection between fiction and life", a form of pre-figuring of the life-world that is configured and refigured in "as we return from narrative text back to action." ${ }^{\prime 31}$ For Jantzen, violent performance appears as the active repetition of the conditions provided by, or mediated through the lens of, deeply engrained mythos (or, a religiosity that conditions the politico-moral imagination of cultures) that takes shape in necrophiliac forms of Western thanatisation. Her analysis maintains that "the west ... [is] in the grip of a cultural neurosis of which its death-dealing structures are symptoms". ${ }^{32}$ It erupts in moments of fear-inducing and insecuring scarcity, crisis, and disaster out of the mythos that identifies self-and-other.

Articulating what is here involved necessitates observing the pathologies that manifest themselves in destructive behaviour, and which concomitantly refuse to face the absurdity of our regulative delusions. There is a deep and eminently practical need to circumvent the laziness of appeals to Manichaean rhetoric, with its attendant scapegoating mechanism that alienates others and comforts the self through a 'politics of purity', and which exhibits itself in a form of moral insensitivity made adiaphorous by the ideological conditioning. As Leonidas Donskis claims in conversation with Zygmunt Bauman, "It turns out that a 'healthy and normal person' can for a time turn into as much of a moral idiot as a sadistic sociopath." 33

Even so, Jantzen's critically parodic account of thinking for an intellectually therapeutic otherwise-in-being remains, however, an insufficient one that tends to generalise with broad brush binaries between East and West, and that has the potential for flattening the multiple differences within the so-called Western tradition. More crucially, then, she does not adequately describe the multiple layers of violent forms of identification and performance. Girard is more promising here when reflecting on the contribution of mimetic desire to generating violence so that sacralised violence is not the state of exception but is the expression of a normalised order that emerges from a certain prevalent kind of social order itself. Inscribed into the social order are patterns of othering that, under certain conditions, turn deadly.

Nonetheless, the marking of sameness and difference in and of itself does not necessitate violence. The crucial hesitation for Girard is that violence erupts only under certain conditions, usually of some kind of threat of scarcity, whether that threat be real or perceived. Yet that coming to violence is irreducibly related to the differentiations, the making strange, and this is culturally represented in, and repeated from, what Mary Midgley calls "the myths we live by" ${ }^{34}$ In terms of this mimetic rivalry the stranger is always placed in a precarious position, according to Girard, even when there are attempts at hybridising integration (think of the Harry Potter pure-blood eligibility criteria for membership of the House of Slytherin that refuses any compromising of pure magical genetics). Post-colonial criticism, for instance, suggests identifications of imposition of patterns of sameness that disallow for difference as a virtuous plenitude in any configuration.

Science fiction is a complex and diffuse genre that is frequently concerned with matters of difference and otherness, and as with all forms of storytelling, strategically provides its own evaluative

31 (Kearney 2001, pp. 132,

32 (Jantzen 2004, p. 4).

33 Leonidas Donskis, in (Bauman and Donskis 2013, p. 37).

34 (Midgley 2003) 
criteria for making judgments in this regard. ${ }^{35}$ Even though crucial questions remain concerning the success of Lucas' space opera and fantasy movies with regard to liberatively democratic portrayals of matters of race, gender, and class, it has been suggested that his Star Wars attempted to critique forms of difference that resulted in exclusionary performance. ${ }^{36}$ The use of the droids in A New Hope to complicate racism is evident in the Mos Eisley barkeeper's exclusionary sneer to Luke "we don't serve their kind here". Leia had, moreover, in one early draft been designed as the main protagonist, but replaced by Luke as much for the sake of appealing to the male dominated audience of science fiction movies as for anything else. Even then, her sassy temperament and confident independence of character has received broadly positive comment from range of feminist analysts.

Where the saga's texts have attracted substantial critical comment is in their politicising of the central conflict between Empire and Rebellion. Lucas' confrontation of unhealthy social division in what Christopher Lasch has called the narcissistic culture of the 1970s still landed his films in trouble over the potential national binarisms and the supposed embedding of reactionary conservative politics expressed in the form of cultural nostalgia. ${ }^{37}$ After all, the opening screen crawls provide the lens through which to responsively view with sympathetic identification and exclusionary derision, with their decisive use of terms such as "evil ... sinister agents" (A New Hope), "a dark time ... dreaded Imperial starfleet ... evil" (Empire Strikes Back, 1980), "vile gangster ... dreaded Death Star" (Return of the Jedi, 1983), "deadly ... greedy" (The Phantom Menace, 1999), "evil ... ruthless ... fiendish" (Revenge of the Sith, 2005). Crucially, this discourse stands in marked contrast with the descriptions of the Jedi and the Republic in terms of their defence of "peace and justice in the galaxy" (The Phantom Menace), "peace and order in the galaxy" (Attack of the Clones, 2002), and the Rebellion in terms of being "a group of freedom fighters" (Empire Strikes Back) who are "struggling" (Return of the Jedi) "to restore freedom to the galaxy" (A New Hope, Return of the Jedi). Speaking of a politics "perpetuating its own self-blindness," Eagleton observes how moral reflexivity is deferred by the morally simplistic character of a variety of euphemisms, slogans, and images. ${ }^{38}$ According to one critic, Star Wars "is accessible, inspirational, and offers a clear view of the world, unmuddled by complexity. Good is good, evil is evil. It is this very factor that is offered as another reason to view Star Wars as apolitical: the nostalgia for simpler times (and simpler entertainments)—Lucas sought to re-create the films of his boyhood." ${ }^{\prime 39}$

Nevertheless, Lucas' Empire Strikes Back and Return of the Jedi offer deconstructions of the traces of politically nostalgic reactiveness, a process intensified further in the prequels, something that demands a hermeneutical estrangement of the impression of $A$ New Hope. This sharpening of the political sensibility in the majority of the movies in the saga sets in particularly sharp relief the political binarism undergirding J. J. Abrams' The Force Awakens with its "post-9/11 setting". While this movie is readily dependent on A New Hope for much of its narrative shape, aesthetic, and characterisation, the cultural contexts are markedly different which then indicates that the tactical decisions are noteworthily those that constitute something less of a retrofitting than of a political revisioning within the ideological refraction of a political rivalry that invents a simple solution to a complex problem.

Firstly, with regard to matters of gender and race, it is evident that there has been a shift in representation with the integration of the black Finn, the Hispanic Poe Dameron, the female characters

35 Kearney: "Storytelling ... is never neutral. Every narrative bears some evaluative charge regarding the events narrated and the actors featured in the narration.... [E]ach narrative carries its own weightings regarding the moral worth of its characters, and dramatises the moral relationship between certain actions and their consequences.... There is no narrated action that does not involve some response of approval or disapproval relative to some scale of goodness or justice-though it is always up to us readers to choose for ourselves from the various value options proposed by the narrative." (Kearney 2001, p. 155).

36 See (McDowell 2016, chp. 3-4).

37 Referring to the physiologicalisation of the Force in The Phantom Menace's description of the midichlorians, Matthew Wilhelm Kappell asserts that "This thorough re-importation of aristocratic and biological justifications of individual worth confounds the often-ascribed message of rebellion against tyranny. In the end we are simply left with a deeply conservative ideology of hereditary rule." (Kappell 2006, p. 160).

38 Citation from (Eagleton 2005, p. 131).

39 (Wetmore 2005, p. 7). See (Jameson 1983, p. 116). 
of Rey and to a lesser degree Captain Phasma among or around the key protagonists. And yet the proliferation of non-white and non-male characters can also act as a mask that mitigates the critical capacity of the visual text. For example, the interrogation of a white supremacist patriarchalism appears readily to the gaze in Lucas' white-washed Empire in a way that the more ethnically and gender diverse First Order (and even more so, Disney's gender retrofitting of the Empire in Star Wars Rebels series) does not, suggesting a certain cultural blindness in Abrams' Star Wars work to issues of continued racial and gender alienation. ${ }^{40}$ Good science fiction, Adam Roberts argues, "needs to aim not at political correctness, or at an unspoken decency regarding race; instead it should make us think about these issues, confront us with them". ${ }^{41}$ It is not obvious, then, that Abrams' Star Wars provides appropriate conditions for such thinking.

Moreover, what occurs is that these cultural differences are not the primary markers of exclusion in Abrams' movie, a position that is accorded instead to an exclusionary politics. The First Order is entirely other, and purely so by virtue of being no history in the text. Snoke, for instance, is without motivating articulation, even more intensively so than was the case for the self-aggrandising Palpatine. There is some potential for the characterisation of Kylo Ren for a kind of moral slippage or unstable hybridity that contests the solidity of binaristically drawn categories of good and evil, categories, of course, so prominent in certain theo-political accounts. Yet even here The Force Awakens offers little more than a nod towards an explosive emotional reactivity that is referred thinly to the manipulative guidance of Snoke, something of a reference to Sidious' instrumentalising hand on Anakin's shoulder but with a less pronounced sense of the moral transmutation of Ben Solo. It is not obvious where the audience is being invited to feel sym-pathein with his character so as to "suspend our normal protective reflexes" to amplify "the range of those we might emphasise with—reaching beyond family, friends and familiars to all kinds of foreigners." 42 Of course, the same needs to be asked about what went wrong in his formation in order to feel so little co-responsibility as to co-operate in genocidal action. As Kearney argues, such atrocities suppose "a radical failure of the narrative imagination", of thinking himself into the place of the victims. ${ }^{43}$

The difficulty is that it is not clear from The Force Awakens that this has been offered, and this has the consequence of denying the personnel of the First Order their complex humanity in a way that contextualises their actions of inhumane violence. The potential for a heterological irresponsibility, then, looms large here. A morally simplistic politics of blame that involves a substantial process of moral othering denies deep causal currents. Accordingly, the American monomyth functions best when it secures self and other within a dualistic logic, generating no complicating questions and permitting little-to-no capacity for self-reflection.

One of the few moments of visible development, change, and therefore history is that of Finn's coming to self-awareness. His non-biologically determined indoctrination in the ideology of dominating power may well offer less of a nod towards breaking the chains of slavery (after all, the slaves were not direct servants of the martial order), however, than to the moral relief involved in the coming-to engage with the Americanised Resistance to an Americanised theologically rooted version of geopolitical order and disorder.

\section{The Disposability of the Other as Alien}

According to post-colonial theorist Gautam Basu Thakur,

The global subject of the West still relies on discourses of enterprise and the othering of the Other for legitimizing its condition of being .... Subject-production in globalization remains

\footnotetext{
40 For more substantial discussion of these matters, see (McDowell 2019).

41 (Roberts 2006, p. 98).

42 (Kearney 2001, p. 138)

43 (Kearney 2001, p. 139).
} 
singularly dependent on strategies of othering the Other, though such acts are cloaked in rhetoric of multicultural tolerant pluralism. ${ }^{44}$

The nature of 'otherness', of what Edward Said describes as the differentiating identification framework of the us and the not-us, commonly pervades the consciousness of science fiction literature and film in a way that is, to use Ursula Le Guin's terms, "not predictive" but "is [culturally] descriptive". ${ }^{45}$ This is one of the reasons it has attracted the critical attention of multiple race and postcolonial readers. The way that otherness is represented, then, becomes crucial for understanding the political significance (subjectivity as being-as-responsible-together) of the texts, and of the movements of power. So, Kearney argues, "In an age crippled by crises of identity and legitimation, it would seem particularly urgent to challenge the polarization between Us and Them." ${ }^{\prime 6}$ Here the category of the monstrous to mythically depict the alien, stranger, foreigner, is telling. "'Monsters'", Kearney declares, "signal the borderline experiences of uncontainable excess, reminding the ego that it is never wholly sovereign." 47 The way he morally sets this up is through Girard's projective notion of scapegoating so that we "attempt to simplify our existence by scapegoating others as 'aliens'. So doing we contrive to transmute the sacrificial alien into a monster, or into a fetish-god. But either way, we refuse to recognize the stranger as a singular other who responds, in turn, to the singular otherness in each of us. We refuse to acknowledge ourselves-as-others." ${ }^{\prime 8}$ As Girard proclaims, the victim as monster is "hard to recognize as a victim because he is totally monstrous", and, simultaneously, the violence of the victimisers' is elided by the "permanent concealment of its [viz., scapegoating persecution's] origins in collective violence." ${ }^{49}$

Three moments in The Force Awakens are significant in this regard: a politics of blame and innocence, the precarious community, and the dehumanised other.

While it is far from a recent invention, particularly given the Puritan apocalyptic political messianic complex, American cinematic representations since 9/11 have functioned with a pronounced appeal to a duality of blame and innocence. ${ }^{50}$ What appears is an intensified version of the moral simplisms that come with and from what Robert Jewett and John Shelton Lawrence describes as the American monomyth, "the zealous cult of the nation". ${ }^{51}$ When represented cinematically this has increasingly taken the form of the innocent (for which read 'American') suffering unjustly and unexpectedly at the hands of terrorist activities by the morally reprehensible (read 'non-Americans'). Terrence McSweeney explains that the representation of "resounding cultural trauma" reproduces "an uncritical and unreflective narrative of American victimization, a pronounced disconnection from the complexities of the geographical arena, and, in some cases, even an elaborate erasure of political and historical context.... These narratives share a conspicuous detachment from disconcerting questions of politics, history and causality. ${ }^{52}$ In fact, as Eagleton laments, "In the so-called war against terror, 'evil' is used to foreclose the possibility of historical explanation." ${ }^{153}$ It is significant, then, that in The Force Awakens the superpower or dominant political system is the New Republic, and it is the First Order that is thereafter cast in the mould of the lesser political power. The Resistance is certainly militarily smaller again, but it is something of a strike team operating to protect the sovereign New Republic. That means that the First Order takes the role of a terrorist organization that possesses a weapon of mass destruction.

According to Stephen Joyce, "It is tempting to assert that everything changed on 9/11; however, the narratives that influenced the American public in its aftermath were not born on that day but pre-written by the history of American exceptionalism and engraved in the popular imagination by Hollywood cinema of the 1990s." (Joyce 2017, p. 222).

(Eagleton 2005, p. 106). 
The resonance of this in the current geopolitical context is markedly dissimilar to that of Lucas' Star Wars movies, especially the first trilogy that had the political fallout over the Vietnam conflict and therefore more consciously depicted issues of colonialism in its background. In this regard, it is telling that General Hux's impassioned speech to his amassed forces, with sizable red and black banners in the background, provides something of a visual reference to Hitler's delivery of powerful rhetoric in venues such as Nuremburg. But Hux's language does not refer to the ethnicity of those internal to the regime that have betrayed it, or to the need for living space for the First Order's Volk. Rather, it centres on moral matters, and in the contemporary world-scene this has another resonance for identifying those to be fought as evil others: the New Republic "lies to the galaxy while secretly supporting the treachery of the loathsome Resistance ... All remaining systems will bow to the First Order." This is a fundamentalism requiring complete political and ideological takeover, a fundamentalism enthusing the gathered ranks against those portrayed as politically decadent. Alan Dean Foster's novelization even uses this language of "decadence" more generally to describe the New Republic. ${ }^{54}$ This characterisation is picked up later when Kylo Ren sneers at Rey and confronts her about "the murderers, traitors, and thieves you call friends." Here the New Republic and the Resistance are as irredeemably "other" to the First Order as it is to them. With such regimes there can be no compromise, no conversation, no co-operation, no negotiation, only conflict and annihilation, only opposition from what is described as "a brave Resistance." In a childish way Abrams even refers to them in an interview as the "baddies." They are binary opposites, but yet in some ways they are mirror images of each other. The resistant conflict is not eschatological as much as apocalyptic, involving not reconciliation and peaceableness as much as all-out conflict to the bitter end. According to Henry Giroux, "Violence has become so normalized that it no longer has a history.... [V]iolence in America is fed by a culture of fear shaped, in part, by a preoccupation with surveillance, incarceration, and the personal security industry. Fear not only undermines trust, it also breeds a hatred of the other and undermines any sense of compassion." 55

To adapt Jantzen's rhetoric for a reconfigured feminist philosophy of religion, this is a mythic construal of a thanatised flourishing, well-being of the commonweal that necessitates the deathly desire of mimetic rivalry. Such a move involves, among other things, a process of dehumanising the singular and uncomplicated 'enemy other', alienating him/her doubly and finally. This renders their lives precarious. Moreover, this involves a privileging of the humanising of the violence perpetrated justifiably by every morally innocent ' $u$ ', a process that is crucially denied to the violence conducted by every 'them'. But by rendering the 'them' as morally monstrously they become pre-eminently disposable, figures of abjection to be cast out without return in a deadly action. The Force Awakens, it would seem, reinforces the basic idea that Campbell claims to be a "basic idea" in the mythologies of war-" that the enemy is a monster and that in killing him one is protecting the only truly valuable order of human life ... one's own people." ${ }^{\prime 56}$

According to Kellner, "Whenever social anxieties proliferate, films and fantasy evoke social [and political] apocalypse". ${ }^{57}$ However, as McSweeney suggests, matters are more politically formative than that would suggest. Post 9/11 cinema he describes memorably as "a cinema of proselytisation", of film not merely visually indexing and reproducing to view cultural anxieties but prolonging and shaping them, regulating how meaning is given to them, and codifying a limited range of possible responses. ${ }^{58}$ What is crucial in this is the sense that the threat-fear nexus is developed in such a way that destroying the evil other is the only way to deal with the difficulty. In this process the heroism of the innocent is intensified by the precariousness of their conditions. This is a theme frequently on

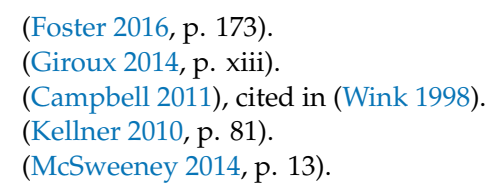


display in post-9/11 cinema. Accordingly, the threat to the fledgling New Republic in The Force Awakens is imposingly portrayed-a superweapon that leaves the mass destructiveness of the Death Star in its wake, and that is contended against by only a modest Resistance force. The depiction of the opposition between the Resistance and the First Order is thereby clean cut. The visual references to Nazism remain not only striking (after all, the First Order emerges from the ashes of the Empire) but are even enhanced by virtue of the loss of Lucas' references to the empires of Rome and the United States. True, the English accented naval officers continue to offer a nod to the British Empire, but without Lucas' implicit critique of America during the Vietnam War. The implication is that the Resistance in The Force Awakens is more akin to the American forces fighting against the terror of British imperialism. ${ }^{59}$ This observation would make sense of an Apocalypse Now-like image. The Tie Fighter attack on Takodana occurs with the screen-filling sun as a backdrop, only now it has John Williams's score rather than Richard Wagner's Flight of the Valkyries. If that textual reference is indeed intended, then the point of Francis Ford Coppola's movie has been entirely missed, since for him it is the American helicopter gunships that are the airborne attack force, while The Force Awakens certainly makes no other equation of the First Order with the United States and its allies in Vietnam.

What is more, the various political contexts of the different sets of movies are significant. Lucas has often mentioned that the real-world context of the classic trilogy was the rising tide of reactionary politics in the United States, from the escalation of the Vietnam conflict through to the ascension to the Oval Office of Ronald Reagan. The plucky band of Rebel fighter terrorists in this milieu play a significant role against the regime of the superpower. So in an early draft of Star Wars in 1973 Lucas envisaged a "large technological empire going after a small group of freedom fighters." 60 During this time he was also working on Apocalypse Now, a movie he would have directed had it not been for its producer's (Francis Ford Coppola) inability to secure a studio that would finance it. Lucas jokes that if he had directed, he would have been run out of the country by the government. In his 1974 notebooks used to evolve the screenplay of Star Wars, he reflects that "The empire is like America ten years from now, after gangsters assassinated the Emperor and were elected to power in a rigged election. ... We are at a turning point: fascism or revolution." ${ }^{161}$ Some of this is kept in the novelisation that anticipated the release of the movie. ${ }^{62}$ The then recent Nixon scandal and its implication of American political life was not far from the surface. On a number of occasions Lucas explicitly claimed that he had designed Palpatine to be, in many ways, a Nixon-like figure. For Lucas, the movie is based around post-colonial worries about "A conflict between freedom and conformity", themes so starkly exhibited earlier in THX 1138. And he lamented that "nobody was aware of that".

A form of mimetic rivalry is in evidence in The Force Awakens, then, one that cannot but erupt in violence under the conditions of scarcity - the scarcity of sovereign control by the First Order, and the vengeful reactivity of the Order to the overthrow of the Empire and the displacement of totalising rule. Violence is submitted to, and naturalised, in what Girard calls "the law of reciprocity." ${ }^{63}$ In the current geopolitical context informed as it has been by "Terror" as "the fundamental concern of American society", the terror inflicted by the First Order that includes the use of a weapon of mass destruction has

59 Missing the complications of the good-evil motif, the connection of Palpatine and Nixon, the Ewoks and the Vietcong, and the prequel allusions to American and British foreign policy through the line "if you're not with me you're my enemy" makes Peter W. Lee's reading a distinctly misplaced and eccentric one: “[Star Wars's] good/bad narrative valorized Americanism with a celebratory portrayal of continual progress and-despite Lucas's claims of a mystical Force overcoming monstrous technological terrors-American mechanical prowess." (Lee 2016, p. 163). He does admit that Lucas claimed Star Wars's "anti-Nam message" later in the paper, Lee does not follow through on the political implications for rereading Star Wars in this light (p. 177).

60 Lucas, cited in (Taylor 2014, p. 88).

61 Cited in (Rinzler 2008, p. 26). According to Lucas, Apocalypse Now "is the kind of film the government will probably run me out of the country for making. ... It's about Americans. It's the same argument as the Wild Bunch: an anti-violence film." Cited in (Baxter 1999, p. 140).

62 See (Lucas 1977, pp. 1f).

63 (Girard 1977, p. 245). 
a quite distinctive resonance. ${ }^{64}$ As Stephen Joyce observes, in post 9/11 cinema, "In order for the US to remain morally innocent, it is vital that the attack on the USA [or anywhere that Americans can identify with] be unprovoked." ${ }^{\prime 65}$ Moreover, there is no reference in The Force Awakens, as there is in A New Hope, to a time of prior peace or even to a hope for a future peaceful reconciliation. Nor has there been any sense of the liberation of colonised peoples for political equity. Nor is there the sense of a single and unified Force that binds all things co-operatively, symbiotically, together, as in Empire Strikes Back. As Lucas observes, "We saw why you cannot blindly set of an atomic bomb, for example. It is one planet and what you do on one side of the planet will affect the entire planet." ${ }^{66}$ Even if Abrams finds a way in Star Wars Episode IX: The Rise of Skywalker to cease the conflict, it will sit uncomfortably with Episode VII. Abrams' and Kasdan's sensibility for Star Wars, it would appear from The Force Awakens, is that it involves a never-ending conflict precisely because it is grounded in an eternal conflict, and one that always requires the violence of an ontological hygene that conflictually engages an 'other' against whom the self must be protected. This framing of the drama is sustained by a less careful prevention of the theological sensibility often blandly referred to as "Manichaean dualism", with its ontological hygene, than has been the case with Lucas' Star Wars. Certainly, the mood of something akin to an eschatological realization of galactic or cosmic peace in Return of the Jedi is both dramatically unrealistic and premature (given, theologically, the drama of life lived before the consummating eschaton or End). Nonetheless, it does at least symbolically offer one vital form of potential resistance to the dominance of a Manichaean sensibility and a perpetual militaristic fantasy promoted to a nation infused with an increasingly romanticised yet "hegemonic and highly aggressive militarism" ${ }^{67}$ This resistant note is enhanced when one bears in mind the language of the fall of Vader in A New Hope, the narrative of the near-fall of Luke (Return of the Jedi), the redemption of Vader (Return of the Jedi), and the tragic parallels of the demise of the Republic, Anakin, and Padmé (Attack of the Clones, Revenge of the Sith). The role of Ben Solo/Kylo Ren in Abrams' reimagined saga's conclusion remains to be seen.

\section{Conclusions}

Theologian Rowan Williams claims that "Since we currently don't seem to know, as a society, what we want to 'induct' children into or what we consider to be the foundation of our society's moral legitimacy (that is, what makes this society worth belonging to or defending), it isn't surprising that we take refuge in treating education as the process of purchasing blocks of training material.... [Yet] the most fundamental issue: how are people to acquire a language in which they can think about the character of their society?"68 Star Wars, as with all cultural products, then, is more than simply entertainment, and a child-friendly version at that. Its cognitive estrangement feeds the collective unconscious in a number of ways. As Paolo Diego Bubbio argues from Girard,

any successful narrative (being it an orally transmitted myth, an ancient tragedy, a novel—or a film) derives its value precisely insofar as it reflects the situation of the community or society in which it is produced, either by concealing or by revealing (and sometimes concealing and revealing at the same time) the mimetic contagion and the spread of violence; and this can happen (and often does happen) despite the conscious intention of the narrative's author(s). ${ }^{69}$

Elements of the saga across the various writers and directors arguably have the potential for offering resistant motifs, in particular the tragic directional arc George Lucas' prequel trilogy has

\footnotetext{
44 Citation from (Wetmore 2012, p. 9).

65 (Joyce 2017, p. 213).

6 George Lucas, in interview with David Sheff (Lucas 1999, p. 154).

67 (Kellner 2008, p. 26).

68 (Williams 2000, pp. 35f).

69 (Bubbio 2019, p. 125). However, my paper would question Bubbio's reading of the violence returning in TLJ "in the form of subversive knowledge." (p. 139).
} 
followed. Yet, bound up within a representation that panders to the sensationalisation of violence, the aestheticisation as entertaining spectacle, and the merchandising production of rapacious desire, is the capacity for mitigation of its politically disruptive capacity by banalising the conflictual. Margaret Miles, then, can make the point that

the millions of Americans who enjoy screen violence, but are not motivated to imitate it, are not unaffected by it. According to ... [a] survey ... , actual and screen violence have similar cumulative effects. Like actual violence, screen violence has been shown to anaesthetize against empathy with the victim's pain.... He [viz., Todd Gitlin] suggests that screen violence functions to habituate Americans to actual violence. Moreover, those who watch screen violence and those who perform violent acts have something in common: desentitization. ${ }^{70}$

In contrast to the nature of this form of political conditioning, Chantal Mouffe claims that the "main task" of hegemony-transformative artistic practices "is the production of new subjectivities and the elaboration of new worlds" so as to "subvert the existing configuration of power."71 This is significant since popular culture can have a significant impact on ordering and configuring the political imagination, even through what Terry Eagleton calls the "pervasive cultural banality". ${ }^{72}$ After all, as religion scholar Brent Plate claims, "Films create worlds. They do not passively mimic or directly display what is 'out there', but actively reshape elements of the lived world and twist them in new ways that are projected onscreen and given over to an audience." Elsewhere Eagleton announces that "What may persuade us that certain human bodies lack all claim on our compassion is culture. Regarding some of our fellow humans as inhuman requires a fair degree of cultural sophistication." ${ }^{\text {"73 }}$ What is required, Eagleton declares through using recognisably theological rhetoric of discipline-for-flourishing, is an "art in the service of the living", a re-education of "our desires". ${ }^{74}$ The contention of this paper has been that if Lucas developed Star Wars to struggle with, among other things, an America that had elected Richard Nixon and engaged in the culturally traumatic Vietnam War, Abrams and his co-writer Lawrence Kazdan have relocated the franchise in a context marked as "post 9/11 cinema". Accordingly, it is unclear quite how The Force Awakens could offer a distinctively interrogatory function for conceiving the flourishing of political subjectivity in the contemporary fractured and self-assertive space of global geopolitics, expressing, as it does, the classificatory coding that figures innocent selfhood in a conflictual relation with the evil terrorist other. Abrams' movie is ill equipped to refuse to naturalise the innocence of the politically regulative civil religion committed to a messianic monomyth of the exceptionalist nation that instils a sensitivity conducive to violence against the foreigner when it is perceived to be under threat. It disables resistance to the production of "a 'violentized' society and individuals for whom violence is a 'normal' mode of conflict resolution and self-assertion, revealing a crisis in values, culture, and consciousness" ${ }^{75}$ Consequently, The Force Awakens politically provides a chilling resource for the political-philosophical-religious critic's reflections on the cultural difficulties of learning about our learning, of the disciplining of desire through monomythic intensification, and of sustaining reaction to cultural trauma through the hostility of the sacred violence enacted in a sacrificial disposal of the other that requires the instrumentalised rationality of the self-secure national subject.

Funding: This research received no external funding.

Conflicts of Interest: The author declares no conflict of interest.

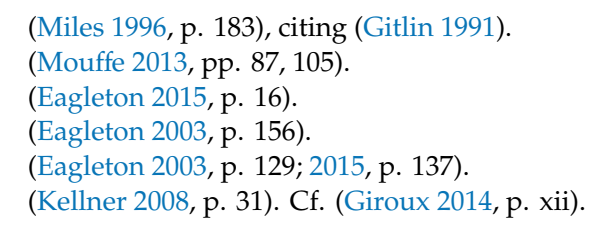




\section{References}

Adorno, Theodor. 1991. The Culture Industry: Selected Essays on Mass Culture. Edited by Jay M. Bernstein. London and New York: Routledge.

Arendt, Hannah. 1969. On Violence. Orlando, Austin, New York, San Diego and London: Harcourt.

Barthes, Roland. 1957. Mythologies. Translated by Anette Lavers. New York: The Noonday Press.

Bauman, Zygmunt, and Leonides Donskis. 2013. Moral Blindness: The Loss of Sensitivity in Liquid Modernity. Cambridge and Malden: Polity Press.

Baxter, John. 1999. George Lucas: A Biography. London: Harper Collins.

Bell, Daniel, Jr. 2001. Liberation Theology after the End of History: The Refusal to Cease Suffering. London and New York: Routledge.

Benjamin, Walter. 1968. Illuminations. Translated by Harry Zohn. New York: Schocken Books.

Bourdieu, Pierre. 1990. The Logic of Practice. Stanford: Stanford University Press.

Bourdieu, Pierre. 1998. On Television. Translated by Priscilla Parkhurst Ferguson. New York: The New Press.

Bourdieu, Pierre, and Loïc Wacquant. 1992. An Invitation to Reflexive Sociology. Translated by Loïc Wacquant. Cambridge: Polity.

Bubbio, Paolo Diego. 2019. A Sacrificial Crisis Not Far Away: Star Wars as Genuine Modern Mythology. In Mimetic Theory and Film. Edited by Paolo Diego Bubbio and Chris Fleming. New York and London: Bloomsbury Academic, pp. 123-49.

Campbell, Joseph. 2011. Myths to Live By. San Anselmo: Joseph Campbell Foundation.

Decker, Mark T. 2016. Industrial Society and the Science Fiction Blockbuster: Social Critique in Films of Lucas, Scott and Cameron. Jefferson: McFarland \& Co.

Eagleton, Terry. 2003. After Theory. London and New York: Penguin Books.

Eagleton, Terry. 2005. Holy Terror. Oxford and New York: Oxford University Press.

Eagleton, Terry. 2015. Hope without Optimism. Charlottesville: University of Virginia Press.

Eagleton, Terry. 2016. Culture. New Haven and London: Tale University Press.

Foster, Alan Dean. 2016. Star Wars: The Force Awakens. London: Century.

Girard, René. 1977. Violence and the Sacred. Translated by Patrick Gregory. Baltimore: The John Hopkins University Press.

Girard, René. 1986. The Scapegoat. Translated by Yvonne Freccero. Baltimore: The John Hopkins University Press.

Girard, René. 2003. Things Hidden Since the Foundation of the World. Translated by Stephen Bann, and Michael Metteer. London: Continuum.

Giroux, Henry A. 2002. Breaking into the Movies: Film and the Culture of Politics. Malden and Oxford: Blackwell.

Giroux, Henry. 2014. Zombie Politics and Culture in the Age of Casino Capitalism, 2nd ed. New York, Washington, Baltimore, Bern, Frankfurt am Main, Berlin, Brussels, Vienna and Oxford: Peter Lang.

Gitlin, Todd. 1991. On Thrills and Kills: Sadomasochism in the Movies. Dissent 38: 245-48.

Hall, Stuart. 1981. The Whites of their Eyes: Racist Ideologies and the Media. In Silver Linings: Some Strategies for the Eighties. Edited by George Bridges and Rosalind Brunt. London: Lawrence and Wisehart.

Hurley, James S. 2001. Titanic Allegories: The Blockbuster as Art Film. Strategies 14: 91-120. [CrossRef]

Jameson, Frederic. 1983. Postmodernism and Consumer Society. In The Anti-Aesthetic. Edited by Hal Foster. Port Townsend: Bay Press.

Jantzen, Grace M. 2004. Foundations of Violence: Death and the Displacement of Beauty. London and New York: Routledge.

Jewett, Robert, and John Shelton Lawrence. 2003. Captain America and the Crusade against Evil: The Dilemma of Zealous Nationalism. Grand Rapids: William B. Eerdmans.

Joyce, Stephen. 2017. Foreshadows of the Fall: Questioning 9/11's Impact on American Attitudes. In American Cinema in the Shadow of 9/11. Edited by Terrence McSweeney. Edinburgh: Edinburgh University Press, pp. 207-24.

Kappell, Matthew Wilhelm. 2006. Eugenics, Racism, and the Jedi Gene Pool. In Finding the Force of the Star Wars Franchise: Fans, Merchandise, and Critics. Edited by Matthew Wilhelm Kappell and John Shelton Lawrence. New York, Washington, Baltimore, Bern, Frankfurt am Main, Berlin, Brussels, Vienna and Oxford: Peter Lang, pp. 159-73.

Kearney, Richard. 2001. On Stories. London and New York: Routledge. 
Kearney, Richard. 2003. Strangers, Monsters, and Gods: Interpreting Otherness. London and New York: Routledge. Kellner, Douglas. 2008. Guys and Guns Amok: Domestic Terrorism and School Shootings from the Oklahoma City Bombing to the Virginia Tech Massacre. Boulder and London: Paradigm Publishers.

Kellner, Douglas. 2010. Cinema Wars: Hollywood Film and Politics in the Bush-Cheney Era. Malden, Oxford and Chichester: Wiley-Blackwell.

Le Guin, Ursula K. 1976. Introduction. In The Left Hand of Darkness. New York: Ace, pp. xi-xvi.

Lee, Peter W. 2016. Periodizing a Civil War: Reaffirming an American Empire of Dreams. In A Galaxy Here and Now: Historical and Cultural Readings of Star Wars. Edited by Peter W. Lee. Jefferson: McFarland Press, pp. 162-88.

Lucas, George. 1977. Star Wars: From the Adventures of Luke Skywalker. London: Sphere Books.

Lucas, George. 1999. George Lucas: Interviews. Jackson: University Press of Mississippi.

Lucas, George, and Bill Moyers. 1999. Of Myth and Men. Time 153.16. April 26. Available online: http: //www.time.com/time/magazine/printout/0,8816,990820,00.html (accessed on 1 April 2005).

McDowell, John C. 2016. Identity Politics in George Lucas' Star Wars. Jefferson: McFarland.

McDowell, John C. 2019. En/Gendering Trouble with J.J. Abrams' Rey in the Force Awakens: Re-Subjecting the Subject to a Performative Subjectivity. Journal of Religion and Popular Culture 31: 16-30. [CrossRef]

McSweeney, Terrence. 2014. The 'War on Terror' and American Film: 9/11 Frames per Second. Edinburgh: Edinburgh University Press.

Midgley, Mary. 2003. The Myths We Live by. London and New York: Routledge.

Miles, Margaret R. 1996. Seeing and Believing: Religion and Values in the Movies. Boston: Beacon Press.

Mouffe, Chantal. 2013. Agonistics: Thinking the World Politically. London and New York: Verso.

Rinzler, Jonathan W. 2008. The Making of Star Wars: The Definitive Story Behind the Original Film. London: Ebury Press.

Roberts, Adam. 2006. Science Fiction, 2nd ed. London: Routledge.

Ryan, Michael, and Douglas Kellner. 1988. Camera Politica: The Politics and Ideology of Contemporary Hollywood Film. Bloomington and Indianapolis: Indiana University Press.

Taylor, Chris. 2014. How Star Wars Conquered the Universe: The Past, Present, and Future of a Multibillion Dollar Franchise. New York: Basic Books.

Thakur, Gautam Basu. 2016. Postcolonial Theory and Avatar. London and New York: Bloomsbury.

Thomson, Ian. 2005. Deconstructing the Hero. In Comics as Philosophy. Edited by Jeff McLaughlin. Jackson: University of Mississippi Press, pp. 100-29.

Wetmore, Kevin J. 2005. The Empire Triumphant: Race, Religion and Rebellion in the Star Wars Films. Jefferson and London: McFarland.

Wetmore, Kevin J. 2012. Post-9/11 Horror in American Cinema. Jefferson: McFarland \& Co.

Williams, Rowan. 2000. Lost Icons: Reflections on Cultural Bereavement. London and New York: T\&T Clark.

Wink, Walter. 1998. The Powers That Be: Theology for a New Millennium. New York: Doubleday. 